\title{
Hyperthyroidism and cardiovascular complications: a narrative review on the basis of pathophysiology
}

\author{
Sibel Ertek ${ }^{1}$, Arrigo F. Cicero ${ }^{2}$
} 1Ufuk University Medical Faculty, Dr. R. Ege Hospital, Endocrinology and Metabolic
Diseases Department, Ankara, Turkey
2Bologna University, Department of Internal Medicine, Aging and Kidney Diseases,
Bologna, Italy

Submitted: 11 March 2012

Accepted: 20 August 2012

Arch Med Sci 2013; 9, 5: 944-952

DOI: 10.5114/aoms.2013.38685

Copyright @ 2013 Termedia \& Banach

\author{
Corresponding author: \\ Sibel Ertek \\ Turkish Ministry of Health \\ Sanliurfa Education \\ and Research Hospital \\ Department of Endocrinology \\ and Metabolic Diseases \\ Esentepe 63100 Sanliurfa \\ Turkey \\ Phone: +90 4143186060 \\ Fax: +90 4143186812 \\ E-mail: sibelertek@yahoo.it
}

\begin{abstract}
Cardiovascular complications are important in hyperthyroidism because of their high frequency in clinical presentation and increased mortality and morbidity risk. The cause of hyperthyroidism, factors related to the patient, and the genetic basis for complications are associated with risk and the basic underlying mechanisms are important for treatment and management of the disease. Besides cellular effects, hyperthyroidism also causes hemodynamic changes, such as increased preload and contractility and decreased systemic vascular resistance causes increased cardiac output. Besides tachyarrythmias, impaired systolic ventricular dysfunction and diastolic dysfunction may cause thyrotoxic cardiomyopathy in a small percentage of the patients, as another high mortality complication. Although the medical literature has some conflicting data about benefits of treatment of subclinical hyperthyroidism, even high-normal thyroid function may cause cardiovascular problems and it should be treated. This review summarizes the cardiovascular consequences of hyperthyroidism with underlying mechanisms.
\end{abstract}

Key words: hyperthyroidism, subclinical hyperthyroidism, overt hyperthyroidism, atrial fibrillation, Graves' disease, toxic nodular goitre.

\section{Introduction}

Thyroid hormones have significant effects on the heart and cardiovascular system through many direct and indirect mechanisms. Since the first descriptions of hyperthyroidism and thyrotoxicosis, the cardiovascular symptoms have been alarming signs for the physician in the clinical presentation of the patient. Palpitations, exercise intolerance, dyspnoea, angina-like chest pain, peripheral oedema and congestive heart failure are common symptoms of hyperthyroidism $[1,2]$ that could show cardiovascular involvement of this relatively frequent endocrinological disorder. Although effects of iodization and world-wide use of radiocontrast agents may change the incidence, overt hyperthyroidism is common and affects $2-5 \%$ of the population $[3,4]$. In hyperthyroid patients mortality is increased by $20 \%$ and the major causes of death are cardiac problems [5]. In the systematic review of Völzke et al., eight studies suggesting a relationship between mortality and hyperthyroidism were evaluated and the relationship was not sufficient for clinical suggestions, except elderly 
patients with subclinical hyperthyroidism [6]. But the association between subclinical hyperthyroidism and mortality in young and middle-aged people remains controversial in the medical literature [7]. Atrial fibrillation, which occurs in an estimated 10$25 \%$ of all overtly hyperthyroid patients, is the most common and worrying complication of hyperthyroidism [8]. This susceptibility to arrhythmic effects of thyroid hormones may have a genetic basis and recently the studies on molecular details of cardiac actions of thyroid hormones revealed some important knowledge [9]. Meanwhile the cause of hyperthyroidism may also change the cardiovascular risk; patients with toxic multinodular goitre have higher cardiovascular risk than patients with Graves' disease, probably because of older age, and patients with Graves' disease may have autoimmune complications, such as valvular involvement, cardiomyopathy and pulmonary arterial hypertension [10].

In this context, the aim of this narrative review is to summarize and organize the available evidence on the cardiac and hemodynamic effects of the thyroid hormones together with the cardiovascular complications of hyperthyroidism.

\section{Molecular and cellular mechanisms of thyroid hormone effects on the heart}

In recent years there has been significant progress to elucidate the molecular mechanisms of cardiac and hemodynamic complications of hyperthyroidism (Table I).

Triiodothyronine (T3) is an active thyroid hormone and it has genetic and cellular effects (on plasma membrane, mitochondria and sarcoplasmic reticulum) on cardiac muscle and blood vessels. Both T3 and T4 are lipophilic and they pass through the cellular membranes and the conversion of T4 to T3 occurs in many cells. T3 acts on THRs (thyroid hormone receptors) in the nucleus, creating dimers of 9-cis-retinoic acid receptor (RXR) [11]: the formed complexes recognize some specific DNA consensus sequences, the thyroid response elements (TRES), located in the enhanced region of the genes to initiate the transcription [12].

In myocytes, thyroid hormones act on many TREs, such as alpha myosin heavy chain fusion $(\mathrm{MHC}-\alpha)$, sarcoplasmic reticulum calcium-activated ATPase (SERCA), the cellular membrane $\mathrm{Na}-\mathrm{K}$ pump (Na-K ATPase), $\beta 1$ adrenergic receptor, cardiac troponin I, and atrial natriuretic peptide (ANP) [13-15], and some genes are also suppressed, such as $\beta$-myosin heavy chain fusion (MHC- $\beta$ ), adenylyl cyclase (IV and V) and the Na-Ca antiporter [16].

Thyroid hormone upregulates $\alpha$, but downregulates $\beta$-chain in myocytes [17]. The final effect of thyroid hormones in animal studies is increased rate of $\mathrm{V} 1$ isoform of $\mathrm{MHC}(\mathrm{MHC} \alpha / \alpha)$ synthesis that is characteristically faster in myocardial fibre short- ening $[16,18]$. A similar effect has also been observed in preliminary human studies $[19,20]$.

Thyroid hormones also have effects on SERCA, which is responsible for the rate of calcium uptake during diastole, by actions on calcium activated ATPase and its inhibitory cofactor phospholamban $[21,22]$. Thyroid hormones enhance myocardial relaxation by upregulating expression of SERCA, and downregulating expression of phospholamban. The greater reduction in cytoplasmic calcium concentration at the end of the diastole increases the magnitude of systolic transient of calcium and augments its capacity for activation of actin-myosin subunits. As confirmation, phospholamban deficient mice showed no increase in heart rate after thyroid hormone treatment [23].

On the plasma membranes, T3 exerts direct extragenic actions on the functions of other ion channels such as $\mathrm{Na} / \mathrm{K}$ ATPase, $\mathrm{Na} / \mathrm{Ca}^{++}$exchanger, and some voltage gated $\mathrm{K}$ channels (Kv 1.5, Kv 4.2, Kv 4.3) affecting myocardial and vascular functions [24, 25] coordinating electrochemical and mechanical responses of myocardium [26, 27]. It prolongs the activation of Na channels in myocardial cells [28] and induces intracellular Na uptake and secondary activation of the $\mathrm{Na}-\mathrm{Ca}$ antiporter, which can partly explain the positive inotropic effect. T3 exerts a direct effect on L-type calcium channels, resulting in abbreviation of action potential duration [29, 30].

The strong inotropic activity of thyroid hormones is probably due to an increased number of $\beta$-adrenergic receptors [31]. Circulating catecholamine levels are in fact the same, but $G$ protein and $\beta$-receptors increase [32]. The sensitivity of the cardiovascular system to adrenergic stimulation is not changed by thyroid hormones [33, 34]. The changes in the heart rate result from both an increase in sympathetic tone and decrease in parasympathetic tone $[35,36]$.

These genomic effects fail to explain fast actions of thyroid hormones on the cardiovascular system. Non-genomic effects promote rapid changes, such as increased cardiac output [37-39]. The hemodynamic consequences of hyperthyroidism and nongenomic changes for plasma membranes occur acutely and contribute to these rapid changes. Studies indicate that thyroid hormone activates acute phosphorylation of phospholamban, and that also partly explains the homology between thyroid hormone and the adrenergic system effects on the heart [35].

In an experimental study on rats, thyroid hormones upregulated connexin-40, a gap junction protein of myocardium important for the transport of electrical activity, and this may be one of the pathogenetic mechanisms of atrial fibrillation in hyperthyroidism [40]. In another animal study the 
Table I. Cardiovascular system-related cellular actions of thyroid hormones

\begin{tabular}{|c|c|c|c|c|c|}
\hline Cell & Cellular target & Action & $\begin{array}{l}\text { Biological and } \\
\text { biochemical effect }\end{array}$ & Clinical effect & References \\
\hline \multirow[t]{6}{*}{ Cardiac myocytes } & MHC- $\alpha$ & Upregulation & $\begin{array}{l}\text { Increased V1 iso- } \\
\text { form }\end{array}$ & \multirow[t]{2}{*}{$\begin{array}{l}\text { Faster myocardial } \\
\text { fibre shortening }\end{array}$} & \multirow[t]{2}{*}[3,6,8]{} \\
\hline & MHC- $\beta$ & Downregulation & $\begin{array}{l}\text { Decreased slower } \\
\text { fibres }\end{array}$ & & \\
\hline & SERCA & Upregulation & \multirow{2}{*}{$\begin{array}{l}\text { Greater reduction } \\
\text { in cytoplasmic cal- } \\
\text { cium concentration } \\
\text { at the end of the } \\
\text { diastole }\end{array}$} & \multirow{2}{*}{$\begin{array}{l}\text { Increased systolic } \\
\text { calcium transient } \\
\text { and ability to acti- } \\
\text { vate muscle fibres }\end{array}$} & \multirow[t]{2}{*}{ [11-13] } \\
\hline & Phospholamban & Downregulation & & & \\
\hline & $\begin{array}{l}\text { Cardiac } \\
\text { troponin I }\end{array}$ & $\begin{array}{l}\text { Increased expres- } \\
\text { sion }\end{array}$ & $\begin{array}{l}\text { Increased synthe- } \\
\text { sis of troponin I in } \\
\text { myocardiocytes }\end{array}$ & $\begin{array}{l}\text { More efficient } \\
\text { contraction }\end{array}$ & [5] \\
\hline & Connexin-40 & Upregulation & $\begin{array}{l}\text { Increased conduc- } \\
\text { tion from atrium to } \\
\text { myocytes and be- } \\
\text { tween myocytes }\end{array}$ & $\begin{array}{l}\text { Improved atrial } \\
\text { connection to fi- } \\
\text { bres }\end{array}$ & [30] \\
\hline \multirow[t]{3}{*}{$\begin{array}{l}\text { Myocardial and } \\
\text { vascular smooth } \\
\text { muscle cells }\end{array}$} & Na-K ATPase & $\begin{array}{l}\text { Increased expres- } \\
\text { sion of the } \alpha \text {-and } \\
\beta \text {-subunits }\end{array}$ & $\begin{array}{l}\text { Increased intracel- } \\
\text { lular K+ especially } \\
\text { in ventricular myo- } \\
\text { cytes }\end{array}$ & $\begin{array}{l}\text { Tendency to hypo- } \\
\text { kalaemic thyrotox- } \\
\text { ic paralysis }\end{array}$ & \multirow[t]{3}{*}[14,15,19,20]{} \\
\hline & $\begin{array}{l}\text { Voltage-gated K } \\
\text { channels }\end{array}$ & $\begin{array}{l}\text { Increased expres- } \\
\text { sion of Kv1.5, } \\
\text { Kv2.1, Kv4.2, Kv4.3 }\end{array}$ & $\begin{array}{l}\text { Delayed rectifier } \\
\mathrm{K}^{+} \text {currents }\end{array}$ & $\begin{array}{l}\text { Changes in action } \\
\text { potential duration }\end{array}$ & \\
\hline & $\mathrm{Ca}^{2+}$ channels & $\begin{array}{l}\text { Inhibition of atrial } \\
\text { L-type calcium } \\
\text { channel expression }\end{array}$ & $\begin{array}{l}\text { Affects calcium } \\
\text { influx }\end{array}$ & $\begin{array}{l}\text { Shorter action po- } \\
\text { tential duration }\end{array}$ & \\
\hline $\begin{array}{l}\text { Vascular smooth } \\
\text { muscle cells }\end{array}$ & $\mathrm{K}^{+}$channels & $\begin{array}{l}\text { Increased } \mathrm{K}^{+} \\
\text {channel activity }\end{array}$ & $\begin{array}{l}\text { Affects contractili- } \\
\text { ty }\end{array}$ & $\begin{array}{l}\text { Vasodilatation, de- } \\
\text { creased PVR }\end{array}$ & [44] \\
\hline $\begin{array}{l}\text { Juxtaglomerular } \\
\text { cells }\end{array}$ & $\begin{array}{l}\beta 1 \text { adrenergic } \\
\text { receptors }\end{array}$ & $\begin{array}{l}\text { Secondary activa- } \\
\text { tion of renin synthe- } \\
\text { sis due to periphe- } \\
\text { ral vasodilatation }\end{array}$ & $\begin{array}{l}\mathrm{Na} \text { retention and } \\
\text { increased blood vo- } \\
\text { lume }\end{array}$ & $\begin{array}{l}\text { Increased heart } \\
\text { rate, decreased } \\
\text { diastolic BP, wider } \\
\text { pulse pressure }\end{array}$ & [45] \\
\hline
\end{tabular}

authors suggested that the connexin-43 phosphorylation was downregulated by $\mathrm{T} 3$ in diabetic rats and decreased adaptation of the heart to hyperglycaemia and this may render the heart prone to ventricular arrhythmias [41]. In fact, thyroid hormone receptor $\alpha 1$ is predominantly expressed in cardiac myocardium and may have an important role in cardiac myoblast differentiation by an ERK kinase dependent process, but its clinical relevance is not known [42]. Also the extracellular signal-regulated kinase (ERK) pathway may have a role in negative cardiac remodelling and decreased cardiac contractile function in hyperthyroidism, by inhibition of the Raf-1/ERK pathway by T3 $[43,44]$.

Administration of a $\beta$-adrenergic receptor antagonist to patients with hyperthyroidism slows the heart rate, but does not alter systolic or diastolic contractile performance $[45,46]$, confirming that thyroid hormone acts directly on cardiac muscle [16, $21,47]$. Meanwhile, thyroid hormone may have direct (without autonomous nervous system) effects on the sinoatrial node $[48,49]$ and oxidative stress in animal studies [50]. The heart rate increases due to increased sinoatrial activity, lower threshold for atrial activity, and shortened atrial repolarisation $[51,52]$. Together with hemodynamic changes, i.e. volume preload increases due to activation of the renin-angiotensin system [53], contractility increases due to increased metabolic demand and the direct effect of the thyroid hormone on heart muscle [54], and systemic vascular resistance decreases because of triiodothyronine-induced peripheral vasodilatation [55], the result is a dramatic increase in cardiac output [56].

Local type 2 iodothyronine deiodinase up-regulation may also be involved in cardiac remodelling via activation of thyroid hormone signalling pathways involving Akt and p38 mitogen-activated protein kinase (MAPK) in thyrotoxic-dilated cardiomyopathy [57]. Preclinical studies in which Akt was 
blocked by an angiotensin-II type 2 receptor blocker showed that this blockage might prevent thyroxine-mediated cardiac hypertrophy [58]. Meanwhile, hypertrophied myocytes may be susceptible to apoptotic stimulation by angiotensin II in hyperthyroidism [59].

All this knowledge could drive the clinician to a more correct treatment choice of hyperthyroidismrelated cardiovascular diseases.

\section{Hemodynamic effects of thyroid hormones}

Beyond what is reported above, hemodynamic effects of thyroid hormones are generally nongenomic and faster, by direct effects on heart and blood vessels. In the peripheral vascular system, the rapid use of oxygen, increased production of metabolic end products and relaxation of arterial smooth muscle fibres by thyroid hormone cause peripheral vasodilatation [24]. This fall in peripheral vascular resistance (PVR) plays the central role in all hemodynamic changes caused by thyroid hormones [60]. Decreased PVR causes an increase in heart rate, a selective increase in blood flow of some organs (skin, skeletal muscles, heart), and a fall in diastolic pressure with consequent widening of pulse pressure. Vasodilatation without an increase in renal blood flow causes a reduction in renal perfusion and activation of the renin-angiotensin system that causes sodium retention and increased blood volume [61]. In addition, thyroid hormones regulate erythropoietin secretion and increased red cell mass may also contribute to the blood volume increase [62]. Improved diastolic relaxation and increased blood volume increased left ventricular end-dias- tolic volume (LVEDV). Reduced PVR and increased LVEDV means increased preload and decreased afterload; thus the stroke volume increases. Increased stroke volume and increased heart rate lead to doubling or tripling of cardiac output, which cannot be solely explained by an increased metabolic rate of the body [63] (Figure 1).

The importance of the contribution of decreased systemic vascular resistance to the increase in systemic blood flow in patients with hyperthyroidism is evidenced by studies in which the administration of arterial vasoconstrictors, atropine and phenylephrine, decreased peripheral blood flow and cardiac output by $34 \%$ in patients with hyperthyroidism but not in normal subjects $[64,65]$.

\section{Overt hyperthyroidism}

Palpitations resulting from an increase in the rate and strength of cardiac contractility are present in the majority of patients, independently from the cause of hyperthyroidism [35]. In overt hyperthyroidism, ambulatory 24-h electrocardiogram monitoring demonstrates that heart rate is constantly increased during the day and exaggerated in response to exercise, and diurnal rhythm is usually unchanged [66].

The most common ECG abnormality is sinusal tachycardia and shortened PR interval, and frequently intra-atrial conduction is prolonged, which is observed as an increase in P wave duration. Intraventricular conduction delay in the form of right bundle branch block is present in around $15 \%$ of patients, and atrioventricular block may also occur due to unknown reasons. Increased dispersion of

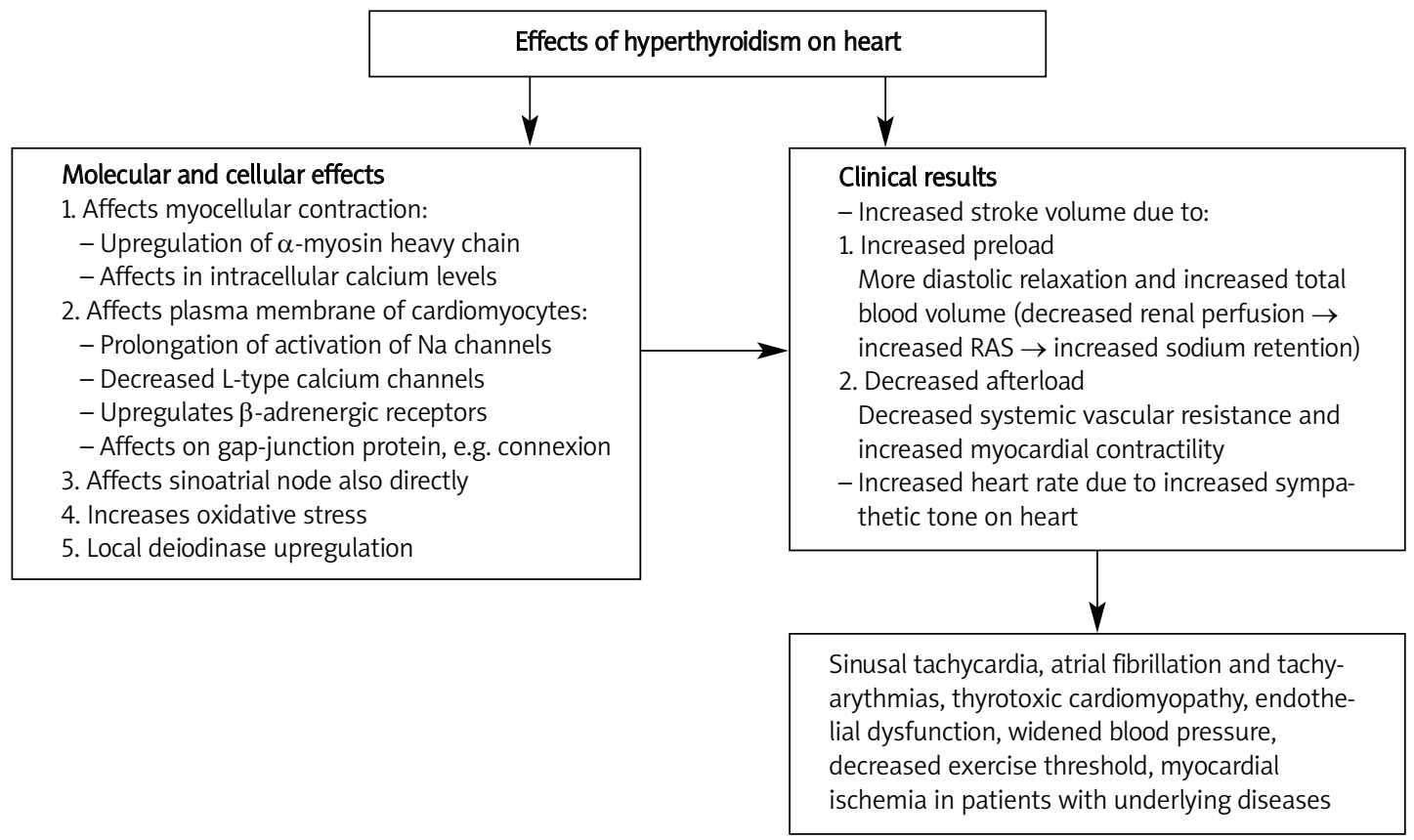

Figure 1. Summary pf molecular and clinical effects of hyperthyroidism on cardiovascular system 
QT interval corrected by the heart rate (QTcD) and pulmonary hypertension may also be observed, but their mechanisms are not clear; the same cardiac and hemodynamic changes together with autoimmunity in Graves' patients may have a role $[67,68]$. Hyperthyroidism is associated with shortened action potential and increased expression of L-type calcium channel 1D, enhances $\mathrm{Na}$ and K permeability, and affects Na pump density [69].

The forced increase in preload and total blood volume increases cardiac work, and myocardial hypertrophy is commonly seen [70].

The most common rhythm disturbance in hyperthyroid patients is sinus tachycardia [35]. Its clinical impact however is overshadowed by that of patients with atrial fibrillation. The prevalence of atrial fibrillation (AF) and less common forms of supraventricular tachycardia in this disease ranges from $2 \%$ to $20 \%$ [71, 72]. When compared with the prevalence of atrial fibrillation of $2.3 \%$ in a control population with normal thyroid function, the prevalence of atrial fibrillation in overt hyperthyroidism was $13.8 \%$, peaking at up to $15 \%$ in patients older than 70 years of age [69]. Atrial fibrillation is generally accompanied by a rapid ventricular response. It is more common in men and its significance increases with age, after 40 years [72].

The majority of patients with hyperthyroidism and AF have an enlarged left atrium when compared to hyperthyroid people with sinus rhythm [73]. As in the case of angina or heart failure, the development of AF should not be attributed only to hyperthyroidism, and the underlying organic heart diseases should be investigated.

Atrial fibrillation usually reverts to sinus rhythm by achievement of a euthyroid state, if the patient is younger and the duration of hyperthyroidism is not long. $\beta$-Adrenergic blockade may be effective to control the ventricular rate. Increased plasma clearance of $\beta$-blockers may necessitate higher doses [74]. Among them propranolol has the advantage of blocking the conversion of T4 to T3 in peripheral tissues, but other cardioselective $\beta$-blockers have a longer half-life and are equally effective on the heart. In cardiac arrhythmias intravascular infusion of calcium blockers should be avoided due to the risk of a further fall in PVR [75]. It is still controversial whether the patients with AF should have anticoagulant therapy to prevent systemic embolization. It is advised to evaluate each patient on a case-by-case basis, and determine the risk of bleeding over embolization [76, 77]. In younger patients with hyperthyroidism and AF who do not have other heart disease, hypertension, or independent risk factors for embolization, the risk of anticoagulant therapy may suppress its benefits. But it would be appropriate to administer anticoagulant agents to older patients with known or sus- pected heart diseases or AF with longer duration. When oral anticoagulants are used, it should be considered that hyperthyroid patients will need smaller doses than euthyroid ones, due to faster elimination of vitamin-K dependent clotting factors [78]

In the patients with AF the maintenance of sinus rhythm is not possible until the euthyroid state is restored, so electrical cardioversion is not recommended without euthyroid status.

Many hyperthyroid patients experience exercise intolerance and exertional dyspnoea, in part because of weakness in the skeletal and respiratory muscle [79] and also due to inability to increase heart rate or lower vascular resistance further, as normally occurs in exercise [80]. The term "high output heart failure" has not been used in the last decades, because it is clear that the heart is still able to increase cardiac output at rest and with exercise. In the setting of low vascular resistance and decreased preload, cardiac functional reserve is compromised and cannot rise further to accommodate the demands of submaximal or maximal exercise [81]. About $6 \%$ of thyrotoxic patients develop heart failure and less than $1 \%$ develop dilated cardiomyopathy with impaired left ventricular systolic dysfunction, due to a tachycardia-mediated mechanism leading to an increased level of cytosolic calcium during diastole with reduced contractility of the ventricle and diastolic dysfunction, often with tricuspid regurgitation [82]. In the recent study of Yue et al., diastolic dysfunction was more prominent in thyrotoxic patients older than 40 years of age, whereas in younger ones a marked reduction in peripheral vascular resistance and increased cardiac output were prominent [83].

Hyperthyroidism may complicate or cause preexisting cardiac disease because of increased myocardial oxygen demand and increased contractility and heart rate, and may cause silent coronary artery disease, anginas or compensated heart failure and even endothelial dysfunction [84]. Treatment of heart failure with tachycardia should include a $\beta$-blocker, considering its contraindications in each patient. Furosemide may help to reverse the volume overload and digoxin is less beneficial when compared with euthyroid heart failure patients, because there may be relative resistance to its action, due to greater blood volume (distribution) and the need to block more Na-K-ATPase in the myocardium [78].

\section{Subclinical hyperthyroidism}

Subclinical hyperthyroidism is a state characterised by low serum thyrotropin levels and normal serum thyroid hormone concentrations. Over the past decades this state has also been found to be associated with some abnormalities in cardiac function. Enhanced systolic function and impaired dias- 
tolic function due to slowed myocardial relaxation may cause increased left ventricular mass in these subjects, together with increased heart rate and arrhythmias, by similar mechanisms as overt hyperthyroidism [85-87]. In people over 60 years of age subclinical hyperthyroidism is associated with tripled risk of atrial fibrillation during a 10-year follow-up period [88]. In a recent cross-sectional study with 29 patients, subclinical hyperthyroidism was found to be related to impaired functional response to exercise with low oxygen consumption and exercise threshold, together with slower heart rate recovery [89]. Patients with subclinical hyperthyroidism show higher QT dispersion and lower heart rate variability, which means impaired sympathovagal balance, increased sympathetic tone in the presence of decreased vagal tone and increased inhomogeneity of ventricular recovery times [90]. Besides antithyroid treatment strategies $\beta$-blocker therapy reduces heart rate and improves left ventricular mass, but positive inotropic response persists [46]. Subclinical hyperthyroidism is associated with increased cardiovascular mortality [91]. In the study of Heeringa et al. with 1426 patients, it was found that even high-normal thyroid function may increase the risk of AF [92]. Besides increased $A F$ and thromboembolic events, increased left ventricular mass and left ventricular function may be the reason. Thus, it is advised to measure serum thyrotropin in all elderly patients with systolic hypertension, widened blood pressure, recent-onset angina, atrial fibrillation and any exacerbation of ischemic heart disease, and treat $[80,93]$.

\section{Conclusions}

Hyperthyroidism is a common thyroid problem which has many effects on almost all organ systems in the body, including bone metabolism, dermatological effects, the gastrointestinal system and the cardiovascular system. Cardiovascular effects are the most common and dangerous effects, and generally they cause the main complaints leading the patient to come to hospital. Cardiovascular actions of thyroid hormones are presented via different mechanisms in the body, including complex and multisystemic interactions. Knowing the details of these mechanisms may provide us with some valuable clues during the treatment of the patients.

Although the most common cause of hyperthyroidism is Graves' disease [94], toxic multinodular thyroid disease is also common, especially in iodine deficient or newly iodinised areas of the world. Meanwhile the patients may be using some medications that may interfere with thyroid functions, such as amiodarone [95] and radiocontrast agents [96] and drugs with fewer side effects and perhaps those without an iodine moiety (such as drone- darone) could be evaluated for arrhythmia treatment [97]. Treatment of hyperthyroidism is important to prevent arrhythmic complications and even a subclinical hyperthyroid state should be treated, especially in high-risk patients. Another important point is prevention of iatrogenic hypothyroidism during treatment, because hypothyroidism also brings some other cardiovascular and general risks [98-100].

In conclusion, thyroid hormones exhibit their cardiovascular effects through different mechanisms and both hyperthyroidism and hypothyroidism have negative effects on the cardiovascular system. In hyperthyroid patients the euthyroid state should be established carefully, and by evaluating each patient with accompanying risks, cause of hyperthyroidism, patient characteristics, comorbidities, and his/her current medications.

\section{References}

1. Ghandour A, Reust C. Hyperthyroidism: a stepwise approach to treatment. J Fam Pract 2011; 60: 388-95.

2. Palitzsch KD. Prevention and multimodal therapy of hyperthyroidism. Internist (Berl) 2008; 49: 1428-36.

3. Wang C, Crapo LM. The epidemiology of thyroid disease and implications for screening. Endocrinol Metabol Clin North Am 1997; 26: 189-218.

4. Bulow PI, Laurberg P, Knudsen $\mathrm{N}$, et al. Increase in incidence of hyprthyroidism predominantly occurs in young people after iodine fortification of salt in Denmark. J Clin Endocrinol Metab 2006; 91: 3830-4.

5. Brandt F, Green A, Hegedüs L, Brix TH. A critical review and meta-analysis of the association between overt hyperthyroidism and mortality. Eur J Endocrinol 2011; 165: 491-7.

6. Völzke H, Schwahn C, Wallaschofski, Dörr M. The association of thyroid dysfunction with all-cause and circulatory mortality: is there a causal relationship? J Clin Endocrinol Metab 2007; 92: 2421-9.

7. Biondi B. Invited commentary: cardiovascular mortality in subclinical hyperthyroidism: an ongoing dilemma. Eur J Endocrinol 2010; 162: 587-9.

8. Petersen P, Hansen JM. Stroke in thyrotoxicosis with atrial fibrillation. Stroke 1988; 19: 15-8.

9. Bielecka-Dabrowa A, Mikhailidis DP, Rysz J, Banach M. The mechanisms of atrial fibrillation in hyperthyroidism. Thyroid Res 2009; 2: 4.

10. Biondi B, Kahaly GJ. Cardiovascular involvement in patients with different causes of hyperthyroidism. Nat Rev Endocrinol 2010; 8: 431-43.

11. Leng X, Bianco J, Tsai SY, Ozato K, O’Malley BW, Tsai MJ. Mechanisms for synergic activation of thyroid hormone receptor and retinoid $X$ receptor on different response elements. J Biol Chem 1994; 269: 31436-42.

12. Ribeiro RC, Apriletti JW, West BL, et al. The molecular biology of thyroid hormone action. Annual N Y Acad Sci 1995; 758: 266-89.

13. Tsika RW, Bahl JJ, Leinwand LA, Morkin E. Thyroid hormone regulates expression of a transfected human alphamyosin heavy chain fusion gene in fetal rat heart cells. Proc Natl Acad Sci USA 1990; 87: 379-83.

14. Zarain-Herzberg A, Marques J, Sukovich D, Periasamy M. Thyroid hormone receptor modulates the expression of 
the rabbit cardiac sarco(endo)plasmic reticulum $\mathrm{Ca}++$ ATPase gene. J Biol Chem 1994; 269: 1460-7.

15. Averyheart-Fullard V, Fraker LD, Murphy AM, Solaro RJ. Differential regulation of slow skeletal and cardiac troponon I mRNA during development and by thyroid hormone in rat heart. J Mol Cell Cardiol 1994; 26: 609-16.

16. Morkin E. Regulation of myosin heavy chain genes in the heart. Circulation 1993; 87: 1451-60.

17. Ojamaa K, Klemperer JD, MacGlivray SS. Thyroid hormone and hemodynamic regulation of beta-myosin heavy chain promoter in the heart. Endocrinology 1996; 137: 802-8.

18. Izumo S, Nadal-Ginard B, Mahdavi V. All members of the $\mathrm{MHC}$ multigene family respond to thyroid hormone in a highly tissue-specific manner. Science 1986; 231: 597-600.

19. Ladenson PW, Sherman SI, Boughman RL. Reversible alterations in myocardial gene expression in a young man with dilated cardiomyopathy and hypothyroidism. Proc Natl Acad Sci USA 1992; 89: 5251-5.

20. Magner J, Clarck W, Allenby P. Congestive heart failure and sudden death in a young woman with thyrotoxicosis. West J Med 1988; 110: 759-60.

21. Dillman WH. Biochemical basis of thyroid hormone action in the heart. Am J Med 1990; 88: 626-30.

22. Kiss E, Jakab G, Kranias EG, et al. Thyroid hormoneinduced alteration in phospholamban protein expression: regulatory effects on sarcoplasmic reticulum $\mathrm{Ca2}+$ transport and myocardial relaxation. Circ Res 1994; 75: 245-51.

23. Kiss E, Brittsan AG, Elds I, et al. Thyroid hormone-induced alterations in phospholamban deficient mouse hearts. Circ Res 1998; 83: 608-13.

24. Panagoulis C, Halapas A, Chariatis E, Driva P, Matsakas E. Hyperthyroidism and heart. Hellenic J Cardiol 2008; 49: 169-75.

25. Kasturi S, Ismail-Beigi F. Effect of thyroid hormone on the distribution and activity of $\mathrm{Na}$, $\mathrm{K}$ ATPase in ventricular myocardium. Arch Biochem Biophys 2008; 475: 121-7.

26. Glick GG, Melikian J, Ismail-Beigi F. Thyoid enhancement of rat myocardial $\mathrm{Na} / \mathrm{K}$ ATPase preferential expression of alpha 2 activity on mRNA abundance. J Membr Biol 1990; 115: 273-82.

27. Ojamaa K, Sabet A, Kenessey A, et al. Regulation of rat cardiac Kv 1.5 gene expression by thyroid hormone is rapid and chamber specific. Endocrinology 1999; 140: 3170-6.

28. Dudley SC Jr, Baumgarten CM. Bursting of cardiac sodium channels after acute exposure to 3,5,3'-triiodo-L-thyronine. Circ Res 1993; 73: 301-13.

29. Walker JD, Crawford FA Jr, Mukherjee R, Spinale FG. The direct effects of 3,5,3'-triiodo-L-thyronine (T3) on myocyte contractile processes. Insights into mechanisms of action. J Thorac Cardiovasc Surg 1995; 110: 1369-79.

30. Chen WJ, Yeh YH, Lin KH, Chang GJ, Kuo CT. Molecular characterisation of thyroid hormone-inhibited atrial Ltype calcium channel expression: implication for atrial fibrillation in hyperthyroidism. Basic res Cardiol 2011; 106 163-74.

31. Hammond HK, White FC, Buxton IL, Salzstein P, Brunton LL, Longhurst JC. Increased myocardial beta-recepors and adrenergic responses in hyperthyroid pigs. Am J Physio 1987; 252: H283-90.

32. Levey GS, Klein I. Cathecholamine thyroid hormone interactions and the cardiovascular manifestations of hyperthyroidism. Am J Med 1990; 88: 642-6.

33. Hoit BD, Khoury SF, Shao Y, Gabel M, Liggett SB, Walsh RA. Effects of thyroid hormone on cardiac beta-adrenergic responsiveness in conscious baboons. Circulation 1997; 96: 592-8.
34. Ojamaa K, Klein I, Sabet A, Steinberg SF. Chnages in adenylyl cyclase isoforms as a mechanism for thyroid hormone modulation of cardiac beta adrenergic receptor responsiveness. Metabolism 2000; 49: 275-9.

35. Cacciatori V, Bellavere F, Pessarosa A, et al. Power spectral analysis of heart rate in hyperthyroidism. J Clin End Metab 1996; 81: 2828.

36. Klein I, Ojamaa K. Thyrotoxicosis and the heart. Endocrinol Metab Clin North Am 1998; 27: 51-62.

37. Davis PJ, Davis FB. Acute cellular actions of thyroid hormone and myocardial function. Ann Thorac Surg 1993; 56 (Suppl.): S16-23.

38. Klemperer JD, Klein I, Gomez M, et al. Thyroid hormone treatment after coronary artery by-pass surgery. N Eng J Med 1995; 333: 1522-7.

39. Walker JD, Crawford FA, Kato S, et al. The novel effects of 3,5,3'-triiodo-L-thyronine on myocyte contractile function and beta adrenergic responsiveness in dilated cardiomyopathy. J Thorac Cardiovasc Surg 1994; 108: 672-9.

40. Almeida NA, Corderio A, Machado DS, et al. Connexin 40 messenger ribonucleic activity is posotovely regulated by thyroid hormone (TH)acting in cardiac atria via the TH receptor. Endocrinology 2009; 150: 546-54.

41. Lin H, Mitasikova M, Dlugosova K, et al. Thyroid hormones suppress epsilon PKC-signalling, downregulate connexin43 and increase lethal arrhythmia susceptibility in nondiabetic and diabetic rats. J Phsiol Pharm 2008; 59: 271-85.

42. Pantos C, Xinaris C, Mourouzis I, et al. Thyroid hormone receptor alpha 1: a switch to cardiac cell "metamorphosis"? J Physiol Pharmacol 2008; 59: 253-69.

43. Suarez J, Scott BT, Suarez-Ramirez JA, Chavira CV, Dillmann WH. Thyroid hormone inhibits ERK phosphorylation in pressure overload induced hypertrophied mouse hearts through a receptor-mediated mechanism. Am J Physio Cell Physiol 2011; 299: C1524-9.

44. Haddad F, Jiang W, Bodell PW, Qin AX, Baldwin KM. Cardiac myosin heavy chain gene regulation by thyroid hormone involves altered histone modifications. Am J Physiol Heart Circ Physiol 2010; 299: H1968-80.

45. Mintz G, Pizzarello R, Klein I. Enhanced left ventricular diastolic function in hyperthyroidisim: noninvasive assessment and response to treatment. J Clin Endocrinol Metab 1991; 73: 146-50.

46. Biondi B, Fazio S, Carella C, et al. Control of adrenergic overactivity by beta-blockade improves the quality of life in patients receiving long-term suppressive therapy with levothyroxine. J Clin Metab 1994; 78: 1028-33.

47. Ojamaa K, Kenessey A, Klein I. Thyroid hormone regulation of phospholamban phosphorylation in the rat heart. Endocrinology 2000; 141: 2139-44.

48. Valcavi R, Menozzi C, Roti E, et al. Sinus node function in hyperthyroid patients. JCEM 1992; 327: 94-8.

49. Sun ZQ, Ojamaa K, Nakamura TY, et al. Thyroid hormone increases pacemaker activity in rat neonatal atrial myocytes. J Moll Cell Cardiol 2001; 33: 811-24.

50. Messarah M, Saoudi M, Boulakaud MS, Feki AE. Oxidative stress induced by thyroid dysfunction in rat erythrocytes and heart. Environ Toxicol Pharmacol 2011; 31: 33-41.

51. Cacciatori V, Bellavere F, Pezzarossa A, et al. Power spectral analysis of heart rate in hyperthyroidism. J Clin Endocrinol Metab 1996; 81: 2828-35.

52. Bielecka-Dabrowa A, Mikhailidis DP, Rysz J, Banach M. The mechanisms of atrial fibrillation in hyperthyroidism. Thyroid Res 2009; $2: 4$.

53. Resnick LM, Laragh JH. Plasma rennin activity in syndromes of hyroid hormone excess and deficiency. Life Sci 1982; 30: 585-6. 
54. Polikar R, Burger AG, Scherer U, Nicod P. The thyroid and the heart. Circulation 1993; 87: 1435-41.

55. Ojamaa K, Klemperer JD, Klein I. Acute effects of thyroid hormone on vascular smooth muscle. Thyroid 1996; 6: 505-12.

56. Klein I, Ojamaa K, Thyroid hormone and the cardiovascular system. N Eng J Med 2001; 344: 501-9.

57. Wang Y, Morimoto S, Du CK, et al. Up-regulation of type2 iodothyronine deiodinase in dilated cardiomyopathy. Cardiovasc Res 2010; 87: 636-46.

58. Carneiro-Ramos MS, Dinis GP, Nadu AP, et al. Blockage of angiotensin-II type 2 receptor prevents thyroxinemediated cardiac hypertrophy by blocking Akt action. Basic Res Cardiol 2010; 105: 325-35.

59. Wang $Y$, Jiao B, Guo WG, Che HL, Zu ZB. Excessive thyroxine enhances susceptibility to apoptosis and decreased contractility of cardiomyocytes. Moll Cell Endocrinol 2010; 320: 65-75.

60. Park KW, Dai HB, Ojamaa K, Lowenstein E, Klein I, Sellke FW. The direct vasomotor effect of thyroid hormones on rat skeleteal muscle resistance arteries. Anesth Analog 1997; 85: 734-8.

61. Resnick LM, Laragh JH. Plasma renin activity in syndromes of thyroid hormone excess and deficiency. Life Sci 1982; 30: 585-6.

62. Klein I, Levey GS. Unusual manifestations of hypothyroidism. Arch Intern Med 1984; 144: 123-8.

63. Fadel BM, Ellahham S, Ringel MD, Lindsay J, Wartofsky L, Burman KD. Hyperthyroid heart disease. Clin Cardiol 2000; 23: 402-8.

64. Kontos HA, Shapiro W, Mauck HP Jr, Richardson DW, Patterson JL Jr, Sharpe AR Jr. Mechanism of certain abnormalities of the circulation to the limbs in thyrotoxicosis. J Clin Invest 1965; 44: 947-56.

65. Theilen EO, Wilson WR. Hemodynamic effects of peripheral vasoconstriction in normal and thyrotoxic subjects. J Appl Physiol 1967; 22: 207-10.

66. von Olshausen K, Bischoff S, Kahaly G, et al. Cardiac arrythmias and heart rate in hyperthyroidism. Am J Cardiol 1989; 63: 930-3.

67. Guntekin U, Gunes Y, Tuncer M, et al. QTc dispersion in hyperthyroidism and its association with pulmonary hypertension. Pacing Clin Electrophysiol 2009; 32: 494-9.

68. Silva DR, Gazzana MB, John AB, Sigueira DR, Maia AL, Barreto SS. Pulmonary arterial hypertension and thyroid disease. J Bras Pneumol 2009; 35: 179-85.

69. Bielecka-Dabrowa A, Mikhailidis DP, Rysz J, Banach M The mechanisms of atrial fibrillation in hyperthyroidism. Thyroid Res 2009; 2: 4.

70. Shimizu T, Koide S, Noh YJ, et al. Hyperthyroidism and the management of atrial fibrillation. Thyroid 2002; 12: 489.

71. Auer J, Scheibner P, Mische T, et al. Subclinical hyperthyroidism as a risk factor for atrial fibrillation. Am Heart J 2001; 142: 838

72. Vardas PE, Mavrakis HE. Atrial fibrillation: a symptom treated as a disease? Hellenic J Cardiol 2006; 47: 191-3.

73. Iwasaki T, Naka M, Hiramatsu K, et al. Echocardiographic studies on the relationship between atrial fibrillation and atrial enlargement in patients with hyperthyroidism of Graves' disease. Cardiology 1989; 76: 10-7.

74. Shenfield GM. Influence of thyroid dysfunction on drug pharmacokinetics. Clin Pharmacokinet 1981; 6: 275-97.

75. Nakazawa HK, Sakurai K, Hamada N, Momotani N, Ito K. Management of atrial fibrillation in the post-thyrotoxic state. Am J Med 1982; 72: 903-6.

76. Petersen $P$, Hansen JM. Stroke in thyrotoxicosis with atrial fibrillation. Stroke 1988; 19: 15-8.
77. Gilligan DM, Ellenbogen KA, Epstein AE. The management of atrial fibrillation. Am J Med 1996; 101: 413-21.

78. Chaudhury S, Ismail-Beigi F, Gick GG, Levenson E, Edelman IS. Effect of thyroid hormone on the abundance of $\mathrm{Na}, \mathrm{K}, \mathrm{ATP}$ ase alpha subunit messenger ribonucleic acid. Mol Endocrinol 1987; 1: 83-9.

79. Klein I, Levey GS. The cardiovascular system in thyrotoxicosis. In: Werner and Ingbar's the thyroid: a fundamental and clinical text. Braverman LE, Utiger RD (eds.). Lippincott and Williams \& Wilkins, Philadelphia 2000; 596-604.

80. Klein I, Ojamaa K. Thyroid hormone and the cardiovascular system. N Eng J Med 2001; 344: 501-9.

81. Kahaly GJ, Kampmann C, Mohr-Kahaly S. Cardiovascular hemodynamics and exercise tolerance in thyroid disease. Thyroid 2002; 12: 473.

82. Dahl P, Danzi S, Klein I. Thyrotoxic cardiac disease. Curr Heart Fail Re 2008; 5: 170-6.

83. Yue WS, Chong BH, Zhang XH, et al. Hyperthyroidisminduced left ventricular diastolic dysfunction: implication in hyperthyroidism-related heart failure. Clin Endocrinol (Oxf) 2011; 74: 636-43.

84. Gu LQ, Zhao L, Zhu W, et al. Relationships between serum levels of thyroid hormones and serum concentrations of symmetric dimethylarginine (ADMA) and N-terminal-proB-type natriuretic peptide (NT-proBNP) in patients with Graves' disease. Endocrine 2011; 39: 266-71.

85. Mercuro G, Panzuto MG, Bina A, et al. Cardiac function, physical exercise capacity, and quality of life during longterm thyrotropin suppressive therapy with levothyroxine: effect of individual dose tailoring. J Clin Endocrinol Metab 2000; 85: 159-64.

86. Shapiro LE, Sievert R, Ong L, et al. Minimal cardiac effects in asymtomatic athyreotic patients cronically treated with thyrotropin supressive doses of L-thyroxine. J Clin Endocrinol Metab 1997; 82: 2592-5.

87. Patane S, Marte F. Changing axis deviation and paroxysmal atrial flutter associated with subclinical hyperthyroidism. Int J Cardiol 2010; 144: e31-3.

88. Sawin CT, Geller A, Wolf PA, et al. Low serum thyrotropin concentrations as a risk factor for atrial fibrillation in older patients. N Eng J Med 1994; 331: 1249-52.

89. Vigario Pdos S, Chachamovitz DS, Teixeira Pde F, Santos MA, Oliveira FP, Vaisman M. Impaied functional and hemodynamic response to graded exercise testing and its recovery in patients with subclinical hyperthyroidism. Arq Bras Endocrinol Metabol 2011; 55: 203-12.

90. Galetta F, Franzoni F, Fallahi P, et al. Changes in autonomic regulation and ventricular repolarisation induced by subclinical hyperthyroidism. Biomed Pharmacol 2010; 64: 546-9.

91. Parle JV, Maisonneuve P, Sheppard MC, et al. Prediction of all cause and cardiovascular mortality in elderly people from one low serum thyrotropin result: a 10 year cohort study. Lancet 2001; 358: 861-5.

92. Heeringa J, Hoogendoorn EH, van der Deure WM, et al. High-normal thyroid function and risk of atrial fibrillation: the Rotterdam Study. Arch Intern Med 2008; 168: 2219-24.

93. Fazio S, Palmieri EA, Lombardi G, Biondi B. Effects of thyroid hormone on cardiovascular system. Recent Prog Horm Res 2004; 59: 31-50.

94. Bartalena L. The dilemma of how to manage Graves hyperthyroidism in patients with associated orbitopathy. J Clin Endocrinol Metab 2011; 96: 592-9.

95. Padmanabhan $\mathrm{H}$. Amiodarone and thyroid dysfunction. South Med I 2010; 103: 922-30. 
96. Rhee CM, Bhan I, Alexander EK, Brunelli SM. Association between iodinated contrast media exposure and incident hyperthyroidism and hypothyroidism. Arch Intern Med 2012; 172: 153-9.

97. Kozlowski D, Budrejko S, Lip GY, et al. Dronedarone: an overview. Ann Med 2012; 44: 60-72.

98. Franco M, Chavez E, Perez-Mendez O. Pleiotropic effects of thyroid hormones: leraning from hypothyroidism. J Thyroid Res 2011; 2011: 321030.

99. Smit JW, Eustatia-Rutten CF, Corssmit EP, et al. Reversible diastolic dysfunction after longterm exogenous subclinical hypothyroidism: a randomized, placebo-controlled study. J Clin Endocrinol Metab 2005; 90: 6041-7.

100. Oszukowska L, Knapska-Kucharska M, Lewinski A. Effects of drugs on the efficacy of radioiodine therapy in hyperthyroid patients. Arch Med Sci 2010; 6: 4-10. 